\title{
PENGARUH PEMBERIAN SUMBER LEMAK BERBEDA DALAM PAKAN TERHADAP PERTUMBUHAN IKAN KUWE, Caranx sexfasciatus
}

\author{
Neltje N. Palinggi, Rachmansyah, dan Usman
}

\begin{abstract}
ABSTRAK
Percobaan pemberian sumber lemak berbeda dalam pakan ikan kuwe telah dilakukan dengan tujuan untuk mendapatkan sumber lemak yang dapat digunakan dalam pakan ikan kuwe. Pemberian sumber lemak dalam pakan ikan kuwe telah dicoba dengan menggunakan minyak ikan $(12 \%)$, minyak cumi $(12 \%)$, dan campuran minyak ikan+minyak cumi+minyak kedelai $(4 \%+5 \%+3 \%)$ dalam pakan yang berkadar protein $37 \%$. Pakan percobaan ini diberikan pada ikan kuwe yang diperoleh dari alam dengan bobot $300-400 \mathrm{~g}$ selama 3 bulan. Wadah yang digunakan adalah jaring apung laut berukuran $1 \times 1 \times 1,2 \mathrm{~m}^{3}$ sebanyak 9 unit dengan kepadatan 5 ekor/keramba. Hasil percobaan menunjukkan pemberian minyak ikan $12 \%$ memberikan laju perturnbuhan harian, konversi pakan, kecernaan protein, dan lemak masing-masing $0,38 \% ; 3,83 \%$; $83 \%$; dan $51 \%$. $\begin{array}{ll}\text { ABSTRACT: } & \text { Effect of dietary lipid sources on growth trevally, Caranx sexfasciatus. By: } \\ & \text { Neltje N. Palinggi, Rachmansyah, and Usman }\end{array}$

The experiment was conducted to determine the effect dietary lipid sources on the growth of trevally fish, Caranx sexfasciatus. Three semipurified diets of $37 \%$ isoprotein contained different lipid sources namely fish oil $(12 \%)$, squid oil (12\%), and fish oil $4 \%+$ squid oil $5 \%+$ soybean oil $3 \%$. These test diets were fed to the fish with initial body weight ranging $300-400 \mathrm{~g}$ for 3 months. They were reared cultured in nine floating net cages of $1 \times 1 \times 1,2 \mathrm{~m}^{3}$ each will a stocking density of 5 ind/cage. The result showed that fish diet containing $12 \%$ fish oil had growth rate of $0,38 \%$; feed conversion ratio of 3,83\%; protein digestibility of $83 \%$ and lipid digestibility of $51 \%$.
\end{abstract}

KEYWORDS: feed, lipid sources, fish oil, squid oil, soybean oil, trevally fish, growth

\section{PENDAHULUAN}

Carangidae mer pakan satu di antara famili ikan laut yang cukup potensial dibudidayakan dalam keramba jaring apung. Salah satu spesies Carangidae, yaitu ikan kuwe (Caranx sp.) memiliki beberapa keuntungan komparatif, di antaranya mampu hidup pada kondisi berjejal mencapai $150 \mathrm{ekor} / \mathrm{m}^{3}$ dengan ukuran awal 20,7-22,5 g (Pongsapan et al., 1994), laju pertumbuhan harian cukup tinggi $1,47 \% \pm$ $0,23 \%$, tanggap terhadap pakan tambahan berupa ikan rucah, konversi pakan cukup efisien 4,63 $\pm 1,85$ dibandingkan dengan famili ikan laut lainnya yang mencapai 10 (Rachmansyah \& Usman, 1993), respons terhadap pakan buatan dalam bentuk moist pelet dengan kadar protein $30 \%-40 \%$, serta digemari konsumen. Sebagian besar usaha budi daya ikan dalam keramba jaring apung masih mengandalkan ikan rucah sebagai pakan. Ikan rucah tidak mengandung nutrisi yang lengkap, sehingga dapat menyebabkan beberapa masalah malnutrisi dan rendahnya sintasan (Boonyaratpalin, 1991). Untuk mengatasi hal tersebut, perlu pemberian pakan buatan yang memenuhi kebutuhan nutrisi ikan kuwe. Lemak adalah salah satu nutrien yang diperlukan ikan kuwe untuk hidup dan pertumbuhannya.

Lemak merupakan sumber energi yang potensial dan mudah dicerna, sebagai pembawa vitamin yang terlarut, komponen membran sel yang menguatkan ketahanan membran, dan meningkatkan absorbsi nutriea. Karena itu, perlu diketahui bahan dasar pakan yang dapat digunakan sebagai sumber lemak yang baik dalam pakan ikan kuwe.

Penelitian ini bertujuan untuk mendapatkan sumber lemak yang dapat digunakan dalam formulasi pakan ikan kuwe.

\section{BAHAN DAN METODE}

Wadah percobaan yang digunakan berupa jaring apung berukuran $1 \times 1 \times 1,2 \mathrm{~m}^{3}$ sebanyak 9 unit yang ditempatkan dengan jarak 1 meter dalam suatu unit rakit di Teluk Labuange, Barru. Hewan uji diperoleh dari perairan sekitar KJA dan diadaptasikan terhadap lingkungan dan pakan yang diberikan. Padat penebaran 5 ekor/keramba dengan bobot awal individu 300-400 g/ekor. Pakan yang dicobakan diformulasi dengan menambahkan sumber lemak yang terdiri atas

\footnotetext{
-) Peneliti pada Balai Penelitian Perikanan Pantai, Maros
} 
minyak ikan, minyak cumi, dan campuran minyak ikan-cumi-kedelai (4:5:3), masing-masing perlakuan tiga ulangan yang disusun dalam rancangan acak lengkap. Formulasi pakan disajikan dalam Tabel 1. Penelitian berlangsung selama 3 bulan. Peubah lemak hewani masih lebih tinggi dibanding pemberian campuran lemak hewani dan nabati. Laju pertumbuhan harian yang diperoleh pada percobaan ini sedikit lebih tinggi dari hasil penelitian Rachmansyah et al. (1999) sebesar 0,24\%--0,27\% pada ikan kuwe yang diberi

Tabel 1. Komposisi pakan percobaan

Table 1. Composition of test diets

\begin{tabular}{|c|c|c|c|}
\hline Bahan baku (Ingredients) & $\begin{array}{l}\text { Minyak } \\
\text { ikan } \\
\text { Fish Oil } \\
\text { (FO) }\end{array}$ & $\begin{array}{l}\text { Minyak } \\
\text { cumi } \\
\text { Squid Oil } \\
(\text { SqO) }\end{array}$ & $\begin{array}{c}\text { Minyak ikan+ minyak } \\
\text { cumi+ minyak kedelai } \\
\text { FO+SqO+SoO }\end{array}$ \\
\hline Tepung ikan (Fish meal) (\%) & 50 & 50 & 50 \\
\hline Tepung kedelai (Soybean meal) (\%) & 18 & 18 & 18 \\
\hline Tepung terigu (Wheat meal) (\%) & 10 & 10 & 10 \\
\hline Tepung tapioka (Cassava meal) (\%) & 8 & 8 & 8 \\
\hline Minyak ikan (Fish oil) (\%) & 12 & - & 4 \\
\hline Minyak cumi (Squid oil) (\%) & - & 12 & 5 \\
\hline Minyak kedelei (Soybean oil) (\%) & - & - & 3 \\
\hline Vitamin mix $(\%)^{\text {a) }}$ & 1 & 1 & 1 \\
\hline Mineral mix $(\%)^{\mathrm{b})}$ & 1 & 1 & 1 \\
\hline \multicolumn{4}{|l|}{ Analisis proksimat (Proximate analysis) } \\
\hline - Protein kasar (Crude protein) & 37.57 & 37.6 & 37.17 \\
\hline - Lemak kasar (Crude lipid) & 16.8 & 15.88 & 16.72 \\
\hline - Serat kasar (Crude fiber) & 3.28 & 5.25 & 4.28 \\
\hline - Kadar abu (Ash) & 11.07 & 11.36 & 11.46 \\
\hline - Kadar air (Moisture) & 4.58 & 5.96 & 5.91 \\
\hline
\end{tabular}

Catatan/note: FO (Minyak ikan/Fish oil); SqO (Minyak cumi/Squid oil); SoO (minyak kedelai/Soybean oil)

a) Vit.A (60.000 IU/g); vit. D3 (12.000 IU/g); vit.E $(120 \mathrm{mg} / \mathrm{g})$; vit. $\mathrm{K} 3(12,5 \mathrm{mg} / \mathrm{g})$; vit.B1 $(10 \mathrm{mg} / \mathrm{g})$; vit. B2 $(25$ $\mathrm{mg} / \mathrm{g})$; vit. B6 $10 \mathrm{mg} / \mathrm{g})$; vit. B12 (0,1 mg/g); vit.C (150 mg/g); folic acid $(5 \mathrm{mg} / \mathrm{g})$; nicotinic acid $(60 \mathrm{mg} / \mathrm{g})$; pantothenate acid (50 mg/g); methionin (50 mg/g); biotin $(0,125 \mathrm{mg} / \mathrm{g})$.

b) Calcium (32,5)\%; phosphor (10\%); iron (6 mg/g); manganese ( $4 \mathrm{mg} / \mathrm{g})$; iodine $(0,075 \mathrm{mg} / \mathrm{g})$; copper $(0,3$ $\mathrm{mg} / \mathrm{g})$; zinc $(3,75 \mathrm{mg} / \mathrm{g})$.

pertumbuhan diamati setiap bulan dengan menimbang hewan uji menggunakan timbangan berketelitian 0,1 g. Sebelum ditimbang ikan uji dibius dengan fenoksi etanol $200 \mathrm{mg} / \mathrm{L}$ untuk menghindari kerusakan fisik akibat gerakan yang kuat dari ikan.

Analisis proksimat dan asam lemak daging ikan uji dilakukan pada awal dan akhir penelitian, juga terhadap bahan dasar pakan dan pakan formulasi. Peubah kualitas air (suhu, salinitas, $\mathrm{pH}$, oksigen terlarut) dipantau untuk menilai kelayakan habitat.

\section{HASIL DAN BAHASAN}

Selama pemeliharaan 3 bulan, ketiga perlakuan yang dicobakan tidak memberikan pengaruh yang nyata $(P>0,05)$ terhadap laju pertumbuhan hariannya (Tabel 2). Laju pertumbuhan harian pada pemberian protein 30\%--40\% dengan pemberian minyak ikan 2\%$-6 \%$.

Hasil uji kecernaan lemak memperlihatkan bahwa minyak ikan dan minyak cumi memberikan nilai kecernaan lemak lebih tinggi dibanding perlakuan campuran minyak ikan-minyak cumi-minyak kedelai (Tabel 2). Hal ini disebabkan karena kadar lemak hewani pada perlakuan campuran minyak ikan + minyak cumi + minyak kedelai lebih rendah dari perlakuan minyak ikan dan minyak cumi. Lemak hewani yang diberikan pada pakan ikan akan memberikan tingkat kecernaan lebih baik daripada lemak nabati. Hal ini dapat terjadi karena lemak hewani yang digunakan berasal dari jenis ikan, sehingga mudah dicerna. Minyak ikan merupakan sumber lemak yang terbaik bagi ikan (Lovell, 1988). Pemberian lemak ke dalam pakan memberikan 
Tabel 2. Pengaruh pemberian sumber lemak dalam pakan ikan kuwe

Table 2. Response of trevally fish, Caranx sexfasciatus to variying source of lipid

\begin{tabular}{lrrr}
\hline \multirow{2}{*}{ Peubah (Variables) } & \multicolumn{3}{c}{ Sumber lemak (Source of lipid) } \\
\cline { 2 - 4 } & \multicolumn{1}{c}{ FO } & SqO & FO+SqO+SoO \\
\hline Pertambahan panjang (Length gain) (cm/ind.) & 2.2 & 1.2 & 1.9 \\
Pertambahan bobot (Weight gain) (g/ind.) & 78.8 & 56.9 & 58 \\
Laju pertumbuhan harian (Daily growth rate) (\%) & 0.38 & 0.34 & 0.27 \\
Rasio konversi pakan (Food convertion ratio) & 3.83 & 4.43 & 4.83 \\
Kecernaan protein (Apparent digestibility of protein) & 83 & 88.46 & 78.63 \\
Kecernaan lemak (Apparent digestibility of lipid) (\%) & 51.37 & 53.75 & 20.91 \\
\hline
\end{tabular}

Catatan/note: FO (Minyak ikan/Fish oil); SqO (Minyak cumi/Squid oil); SoO (minyak kedelai/Soybean oil)

Tabel 3. Kandungan asam lemak dalam sumber lemak pakan, pakan, dan ikan (sebelum dan sesudah penelitian) (\% bobot kering)

Table 3. Fatty acid composition in lipid source, feed, and fish (before and after treatment) (\% dry weight)

\begin{tabular}{|c|c|c|c|c|c|c|c|c|}
\hline $\begin{array}{l}\text { Pakan A } \\
\text { Feed A } \\
(F O)\end{array}$ & $\begin{array}{l}\text { Pakan B } \\
\text { Feed B } \\
\text { (SqO) }\end{array}$ & $\begin{array}{l}\text { Pakan C } \\
\text { Feed C } \\
\text { (FO+SqO } \\
+ \text { SoO })\end{array}$ & $\begin{array}{l}\text { Tepung } \\
\text { ikan } \\
\text { Fish } \\
\text { meal }\end{array}$ & $\begin{array}{l}\text { Minyak } \\
\text { ikan } \\
\text { Fish oil }\end{array}$ & $\begin{array}{l}\text { Sebelum penelitian } \\
\text { filet ikan } \\
\text { Before treatment of } \\
\text { fish fillet }\end{array}$ & $F O$ & $\mathrm{SqO}$ & $\begin{array}{c}\mathrm{FO}+ \\
\mathrm{SqO}+ \\
\mathrm{SoO}\end{array}$ \\
\hline 4.648 & 11.009 & 8.097 & 9.774 & 14.254 & 2.125 & 2.412 & 6.534 & 4.700 \\
\hline 16.028 & 10.759 & 7.772 & 8.013 & 5.638 & 2.510 & 5.037 & 13.059 & 12.895 \\
\hline 10.469 & 4.429 & 3.393 & 4.222 & 8.157 & 16.935 & 5.089 & 1.661 & 1.143 \\
\hline 19.076 & 13.52 & 12.242 & 16.662 & 24.801 & 21.209 & 35.608 & 31.186 & 21.482 \\
\hline 1.004 & 6.364 & 5.013 & 7.722 & 5.383 & 9.442 & - & 3.582 & 2.115 \\
\hline 15.406 & 1.715 & 0.865 & - & 1.922 & 3.965 & 39.443 & - & - \\
\hline 5.442 & 3.48 & 3.515 & 14.99 & 13.611 & 13.18 & - & 36.489 & 49.945 \\
\hline 13.744 & 17.56 & 14.922 & 11.751 & 4.665 & 15.007 & - & -. & - \\
\hline 1.795 & 8.317 & 13.2 & 3.465 & - & 5.383 & - & - & - \\
\hline 0.423 & - & - & 4.326 & 4.607 & - & 0.286 & - & - \\
\hline 1.241 & 1.248 & 3.325 & 3.557 & 3.909 & - & - & 0.792 & 1.585 \\
\hline
\end{tabular}

Catatan/note: FO (Minyak ikan/Fish oil); SqO (Minyak cumi/Squid oil); SoO (minyak kedelai/Soybean oil)

penambahan asam lemak esensial (dokosaheksaenoat $=$ DHA $)$ pada produk ikan yang dihasilkan $($ Tabel 3). Pemberian minyak cumi menyumbangkan DHA yang terbesar dalam daging ikan hasil percobaan. Peran asam lemak DHA penting pada ikan laut karena dapat memberikan pertumbuhan yang baik bagi larva ikan (Takeuchi, 1991; Watanabe, 1988; Kanazawa, 1985). Selain itu asam lemak DHA memberikan kontribusi pada fungsi metabolisme (Ibeas et al., 1997).

Dari percobaan ini terlihat pula adanya pengaruh yang sama pada kecernaan proteinnya, di mana pada tingkat kecernaan lemak yang tinggi menghasilkan kecernaan protein yang tinggi pula. Hal ini dapat terjadi karena asam lemak yang dikandung oleh masingmasing sumber lemak hewani adalah asam lemak yang dibutuhkan oleh ikan kuwe, sehingga dapat memberikan kontribusi pada fungsi metabolismenya, akibatnya mempengaruhi tingkat kecernaan dari proteinnya. Pengaruh kecernaan ini terlihat pula pada daging ikan hasil percobaan (Tabel 4), di mana pemberian lemak dalam pakan memberikan pertambahan protein dalam daging ikan kuwe. Hal ini disebabkan energi yang diperoleh ikan kuwe selama pemeliharaan berasal dari hasil metabolisme lemak, sehingga salah satu fungsi protein yaitu sebagai sumber energi sepenuhnya telah terpenuhi melalui lemak yang ada. Kecernaan nutrien ini mempengaruhi konversi pakan, di mana semakin tinggi tingkat kecernaan nutrien, semakin rendah pula konversi pakannya. Nilai konversi pakan diperoleh 3,83-4,83 lebih tinggi dari nilai konversi yang diperoleh Rachmansyah et al. (1999) yaitu sebesar 3,6-4,1 pada 
Tabel 4. Analisis proksimat ikan kuwe (\% bobot kering)

Table 4. Proximate analysis of trevallies fillet (\% dry weight)

\begin{tabular}{lccccc}
\hline \multirow{2}{*}{$\begin{array}{c}\text { Bahan baku } \\
\text { Ingredients }\end{array}$} & Ikan awal & \multicolumn{4}{c}{ Ikan akhir (Final fish) } \\
\cline { 3 - 6 } & Initial fish & FO & SqO & FO+SqO+SoO \\
\hline Protein kasar (Crude protein) & 67.82 & 75.3 & 81.12 & 77.9 \\
Lemak kasar (Crude lipid) & 2.51 & 4.43 & 1.05 & 1.84 \\
Serat kasar (Crude fibre) & - & - & - & - \\
Abu (Ash) & 7.27 & 7.6 & 18.26 & 22.84 \\
\hline
\end{tabular}

Catatan/note: FO (Minyak ikan/Fish oil); SqO (Minyak cumi/Squid oil); SoO (Minyak kedelai/Soybean oil)

pembesaran ikan kuwe yang diberi pakan buatan berupa pelet.

Kualitas air selama penelitian baik di dalam maupun di luar jaring memperlihatkan nilai yang relatif sama, yaitu salinitas 29,8 ppt; temperatur 28,8 $29,6^{\circ} \mathrm{C}$; dan oksigen terlarut 4,9-5,6 mg/L (Tabel 5). Nilai tersebut masih layak untuk kehidupan dan pertumbuhan ikan kuwe. Hal ini terlihat pada sintasan yang diperoleh rata-rata sebesar $91 \%$.

\section{KESIMPULAN}

Minyak ikan, minyak cumi, dan campuran minyak ikan+minyak cumi+minyak kedelai dengan perbandingan 1:1:1 dapat digunakan sebagai sumber lemak dalam pakan ikan kuwe, masing-masing sebanyak $12 \%$, menghasilkan laju pertumbuhan harian 0,38 0,27 ; dan rasio konversi pakan 4,43-3,83.

\section{DAFTAR PUSTAKA}

Boonyaratpalin, M., 1991. Nutritional studies on sea bass (Lates calcarifer). In S.S. DeSilva (eds). Fish nutritional research in Asia. Proceeding of the fourth Asian fish nutrition workshop. Asian Fish. Soc. Spec. Publ. 5. Asian Fisheries Society, Manila. p. 33--42.

Ibeas, C., J.R. Cejas, R. Fores, P. Badia, T. Gomez, and A.L. Hernandez. 1997. Influence of eicosapentaenoic to docosahexaenoic acid ratio (EPA/DHA) of dietary lipids on growth and fatty acid composition of gilthead seabream (Sparus aurata) juveniles. Aquaculture 150:91--102

Kanazawa, A. 1985. Essensial fatty acid and lipid requirement of fish. In: Cowey, C.B., Mackie, A.M., and Bell, J.G. (Eds). Nutrition and Feeding in Fish. Academic Press, London. p. 281--298.

Lovell, T. 1988. Nutrition and Feeding of Fish. Published by Van Nostrand Reinhold. New York. 260 pp.

Pongsapan, D. S., Rachmansyah, dan Usman. 1994. Budidaya ikan kuwe, Caranx sp. dengan padat penebaran yang berbeda dalam keramba jaring apung di perairan Teluk Ambon bagian dalam. J. Penelitian Budidaya Pantai 10(2): 87--94.

Rachmansyah dan Usman. 1993. Studi pendahuluan pengaruh frekuensi pemberian pakan terhadap pertumbuhan ikan kuwe, Caranx sp. dalam keramba jaring apung. J. Penelitian Budidaya Pantai 9 (4): 65-74.

Rachmansyah, A. Laining, P.R. Pong-Masak, dan A.G. Mangawe. 1999. Respons pertumbuhan ikan kuwe, Caranx sexfasciatus yang diberi pakan dengan level protein berbeda. Laporan Hasil Penelitian Balai Penelitian Perikanan Pantai. 12 pp.

Takeuchi, T.1991. Variety of essensial fatty acids requirement in fish. Kagaku to Seibutsu, 29:571--580.

Watanabe, T. 1988. Nutrition and growth. In C.J. Shepherd and N.R. Bromage (Eds.). Intensive fish farming. BSP Professional Books, London. p. 154--197. 


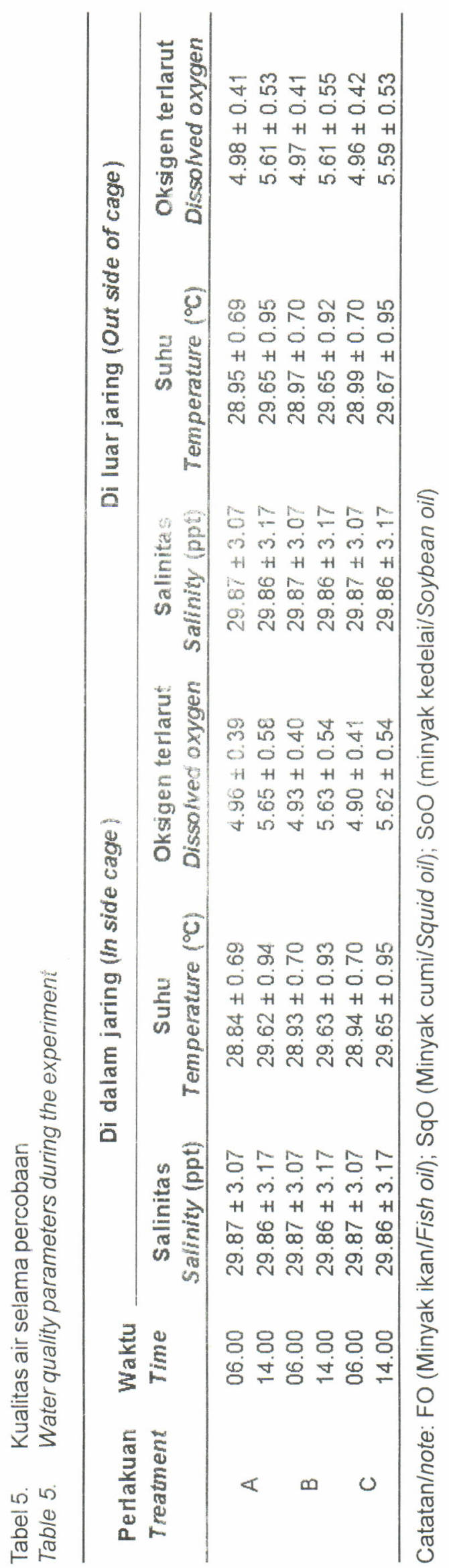


N.N. Palinggi, Rachmansyah, dan Usman 